\title{
Quantifying health aspects of passive smoking in British children aged 5-11 years
}

\author{
Susan Chinn, Roberto J Rona
}

\begin{abstract}
Study objective-The aim was to estimate the dose-response relations of height and respiratory symptoms to passive smoking in children aged 5-11 years.

Design-The study was an analysis of existing observational studies, comprising three samples: English representative; English inner city; Scottish representative. Setting-Primary schools (children aged 5-11 years).

Participants-The study population included 5002 English children from the representative sample $(69 \cdot 1 \%$ of total eligible), 2903 English inner city children $(42 \cdot 0 \%)$, and 3319 representative Scottish children $(75 \cdot 6 \%)$.

Measurements and main results-No significant relation was found between child's height and total parental smoking in the home. Relative risk for persistent wheeze on exposure to 20 cigarettes per day was $1 \cdot 35$, compared to no exposure. Risk of at least one respiratory condition attributable to passive smoking reached $8.1 \%$ in white English inner city children.

Conclusions-The relation of child's height to passive smoking was not substantiated. The risk of respiratory conditions resulting from passive smoking, although small, is not negligible.
\end{abstract}

The National Study of Health and Growth (NSHG), which is a surveillance study including, each year, around 9000 children aged 5-11 years, has previously reported results relating to two effects of passive smoking in children, the first ${ }^{1}$ a possible negative relation between child's height and the reported number of cigarettes smoked by parents in the home, and the second ${ }^{2}$ a doseresponse relation between prevalence of respiratory symptoms and parental smoking. Both reports were from data collected in 1982 from a quasi-representative sample of 4000 English children and nearly 1000 Scottish children.

Many studies have reported increased prevalence of respiratory symptoms in children of parents who smoke compared with children of non-smokers, and this effect now seems established, not only in infants but in preadolescent children. ${ }^{3} 4$ However most studies gave information only on the number of parents who smoked. The lack of information on a doseresponse relation ${ }^{2}$ may have contributed to a previous conclusion ${ }^{5}$ that studies in children were inconsistent. Even when studies were sufficiently large and information available full estimation has not always been provided. Newspiel et $a l^{1}$ reported results from the 1970 British cohort study of 9670 children at 5 and 10 years of age, but included the number of cigarettes smoked by the mother and confounding variables only in an analysis of "wheezy bronchitis". The amount smoked by the father was not considered.

The few studies that have collected data on number of cigarettes smoked have used total smoking rather than smoking in the home. Berkey et $a l^{7}$ reported parental smoking in three categories, 0,1 to 9 , and $10+$ cigarettes per day, for each parent, in an analysis in which they found a significant negative relation between attained height of 6-10 year old children and total maternal smoking, and a lesser non-significant relation with paternal smoking.

In the previous analyses of NSHG data, information on the use of gas for cooking and use of paraffin heaters, which have been reported to be associated with increased prevalence of respiratory symptoms, ${ }^{8}$ was not collected.

In 1983 the design of the NSHG was changed to include children from ethnic minorities and inner city areas in England ${ }^{9}$ in alternate years. Further Scottish areas, selected on the same basis as those in the 1982 sample, were also included. Respiratory symptoms were found to be more prevalent in white and Afro-Caribbean inner city children in 1983 than in white children studied in $1982 .^{8}$ Data on parental smoking were not collected in 1983, but were included in 1987 , together with information on cooking and heating fuels. Comparable data were collected for the quasi-representative samples in 1988.

The data collected in 1987 and 1988 therefore provided the means to estimate the sizes of the relations of a child's height and respiratory symptoms to exposure to parental smoking in the home in a sample in which exposure was expected to be high, and in a larger Scottish sample, and to re-estimate the relation in a representative English sample.

\section{Methods}

In 198720 areas in England and nine in Scotland took part in the NSHG. ${ }^{9}$ Ten of the English areas had been selected as inner city wards, on the criteria of high unemployment, overcrowding, and lack of exclusive use of amenities in the home. Five were selected as having a high proportion of residents born in the Indian subcontinent, and five as having a high proportion from New Commonwealth Africa or the Caribbean. The latter areas tended to share the characteristics of the inner city areas, and the inner city areas tended 
to have a higher proportion than average of ethnic minority residents; all the English areas are therefore referred to as inner city areas. Children in these areas were classified on the basis of language spoken at home and fieldworker's assessment into Caucasian (White), AfroCaribbean, Urdu, Gujarati, Punjabi, Other Asian, Other or Not Known. ${ }^{9}$

In 198822 areas in England and five in Scotland participated. Children are eligible to take part while attending a selected "primary school" or in classes of children aged mainly 5-11 years in other selected schools.

Height was measured on a Holtain stadiometer to the last complete $0.1 \mathrm{~cm}$, as described by Tanner, Whitehouse and Takaishi. ${ }^{10}$ It was expressed as a standard deviation score, the difference between a child's height and that expected for its age and sex, divided by the age-sex specific standard deviation. Means and standard deviations were taken from the 1988 data, for England and Scotland separately.

Data on the child's respiratory symptoms, parental smoking, and family background were obtained from a self administered questionnaire usually completed by the child's mother. In the English inner city areas this is provided as a dual language English-Urdu, English-Gujarati, or English-Punjabi questionnaire as appropriate. The questions on respiratory conditions were, for each child: "Has he or she suffered from either of the following illnesses in the LAST TWELVE MONTHS?' and 'If YES: how many attacks has he or she suffered in the LAST TWELVE MONTHS" for asthma and bronchitis; "Does he or she USUALLY cough first thing in the morning? (excluding clearing throat or single cough);" "Does he or she USUALIY cough at any other time? (excluding clearing throat or single cough);" Does his or her chest ever sound wheezy or whistling?" and "if you answered YEs: "Does he or she get this on MOST days or nights?" The number of cigarettes smoked at home by the father and mother in total was used as the measure of passive smoking in two parent families. The smoking of the single parent only was used for a child in a one parent family with sufficient information. When the number of parents or guardians was not known, or with which the child was living, the data for that child were omitted.

Multiple regression analysis was used to estimate the relation of height standard deviation score to passive smoking, allowing for a number of potentially confounding variables. These are shown in table $I$, and included, with small modifications, those used in the 1982 height analysis. ${ }^{1}$ Ethnic origin was included as an additional independent variable for English children in 1987. Non-white English children in 1988 were excluded, as data on language spoken at home were not available. Uptake of school meals, and whether free, was introduced as an additional variable because of the finding of a strong association of school meals with height in the 1982 and 1983 samples. $^{9}$ First order interactions of ethnic group with the other independent variables were included, but retained in the analysis only if statistically significant.

Asthma and bronchitis were analysed as at least one attack versus no attack. The two questions on cough were combined into a single "usually coughs" condition. Wheeze was analysed as occasional wheeze, that is as a positive answer to the first question, and as persistent wheeze, a positive answer to the second question. Each condition was analysed as a dichotomous, ie, present or absent, dependent variable using multiple logistic regression. In addition to the potentially confounding variables included in the 1982 analysis, ${ }^{3}$ school meals and the use of gas for cooking and of paraffin heaters were included. Children living in Scotland were analysed as one group, but separately from the English representative sample because of different findings in a number of analyses, in particular in the previous relation of respiratory symptoms to passive smoking. ${ }^{2}$

\section{Results}

In 19873007 Scottish children and 6906 English children were eligible to take part in the study. Of these questionnaire data were available for 1544 Scottish boys and 1363 Scottish girls $(96.7 \%)$ and 2898 English boys and 2762 English girls $(82.0 \%)$.

In 1988 the total eligible were 1384 Scottish children and 7237 English children. Questionnaire data were available for 697 Scottish boys and 644 Scottish girls $(97.4 \%), 3462$ English boys, and 3192 English girls $(92 \cdot 1 \%)$. The age range was from 4.04 to 12.78 years in 1987 and from 4.13 to 12.07 years in 1988 , but the vast majority were within the range 5.0 to 11.99 years.
Table I Potentially confounding variables included in the analysis of data on height and respiratory conditions in relation to passive smoking

\begin{tabular}{|c|c|c|}
\hline Independent variable & Height SDS & Respiratory conditions \\
\hline $\begin{array}{l}\text { Passive smoking } \\
\text { Birthweight } \\
\text { Father's social class }\end{array}$ & \\
\hline $\begin{array}{l}\text { Overcrowding (people/room) } \\
\text { Mother's age } \\
\text { One parent family } \\
\text { Mother's education (highest full-time level) }\end{array}$ & \multicolumn{2}{|c|}{$\begin{array}{c}\text { or unskilled manual (IV or V), other or not known. } \\
<1 \cdot 25,>1 \cdot 25 \text {, not known } \\
\text { As continuous variable } \\
\text { No Yes }\end{array}$} \\
\hline $\begin{array}{l}\text { Father's employment status } \\
\text { Mother's smoking in pregnancy } \\
\text { Ethnic origin } \\
\text { School meals } \\
\text { Family size }\end{array}$ & \multicolumn{2}{|c|}{$\begin{array}{c}\text { None or primary, secondary, technical or commercial } \\
\text { college, university or polytechnic, not known. } \\
\text { Employed, not-employed, not known, no father or male guardian } \\
\text { No, Yes, NK } \\
\text { See text } \\
\text { Free, not free, not taken, NK if free, NK }\end{array}$} \\
\hline Family size & $\begin{array}{l}\text { Total number of siblings } \\
\text { (categorical variable) }\end{array}$ & $\begin{array}{c}\text { Total number of siblings } \\
\text { (linear trend) }\end{array}$ \\
\hline $\begin{array}{l}\text { Child's age } \\
\text { Triceps skinfold } \\
\text { Parental heights } \\
\text { Gas cooking/paraffin heater }\end{array}$ & $\begin{array}{l}\text { SDS standardised by age } \\
\text { Not applicable } \\
\text { Included as continuous variables } \\
\text { Not applicable }\end{array}$ & $\begin{array}{l}\text { Included as continuous variable } \\
\text { Included as continuous variable } \\
\text { Not applicable } \\
\text { Neither, gas cooker only, paraffin heater } \\
\text { only, both, not known }\end{array}$ \\
\hline
\end{tabular}


Table II Distribution of cigarettes smoked per day in the home by parents in total, by ethnic group in inner city areas in

England 1987, in 1988 English representative sample and in Scottish 1987 and 1988 samples.
Table III Distribution of cigarettes smoked per day in the home by fathers, by ethnic group in inner city areas in England 1987, in 1988 English representative sample and in Scottish 1987 and 1988 samples.

\begin{tabular}{|c|c|c|c|c|c|c|c|c|c|}
\hline \multirow{4}{*}{$\begin{array}{l}\text { No of cigarettes } \\
\text { smoked in home } \\
\text { per day in total } \\
\text { by parents }\end{array}$} & \multicolumn{8}{|c|}{$\%$ Children exposed } & \multirow{4}{*}{$\begin{array}{l}\text { Scotland } \\
1987 \text { and } \\
1988\end{array}$} \\
\hline & \multicolumn{8}{|c|}{ England } & \\
\hline & \multirow{2}{*}{$\begin{array}{l}\text { Representative } \\
\text { sample } 1988 \\
\text { (white) }\end{array}$} & \multicolumn{7}{|c|}{ Inner city areas 1987} & \\
\hline & & White & $\begin{array}{l}\text { Afro- } \\
\text { Caribbean }\end{array}$ & Urdu & Gujarati & Punjabi & $\begin{array}{l}\text { Other } \\
\text { Asian }\end{array}$ & Other & \\
\hline $\begin{array}{c}0 \\
1-4 \\
5-14 \\
15-24 \\
25-34 \\
\geqslant 35\end{array}$ & $\begin{array}{r}59 \cdot 4 \\
3 \cdot 4 \\
17 \cdot 8 \\
12 \cdot 7 \\
3 \cdot 6 \\
3 \cdot 1\end{array}$ & $\begin{array}{r}31.4 \\
2.4 \\
24 \cdot 6 \\
24 \cdot 0 \\
8 \cdot 4 \\
9 \cdot 2\end{array}$ & $\begin{array}{r}59.3 \\
9.7 \\
21.5 \\
7.0 \\
1.7 \\
0.9\end{array}$ & $\begin{array}{r}70.3 \\
9.2 \\
17.0 \\
2.8 \\
0.7 \\
0.0\end{array}$ & $\begin{array}{r}72.6 \\
11.6 \\
12.4 \\
2.6 \\
0.6 \\
0.2\end{array}$ & $\begin{array}{r}71.8 \\
8.0 \\
14.0 \\
5.3 \\
0.5 \\
0.5\end{array}$ & $\begin{array}{r}46 \cdot 3 \\
5 \cdot 8 \\
37 \cdot 4 \\
8 \cdot 9 \\
0 \cdot 4 \\
1 \cdot 2\end{array}$ & $\begin{array}{r}52 \cdot 3 \\
7.8 \\
23.8 \\
11.7 \\
2.1 \\
2.1\end{array}$ & $\begin{array}{r}51.7 \\
2.5 \\
20.6 \\
15.6 \\
5.6 \\
3.9\end{array}$ \\
\hline $\begin{array}{l}\text { Total number } \\
\text { of children }\end{array}$ & 5888 & 1649 & 583 & 283 & 507 & 1325 & 257 & 512 & 4019 \\
\hline
\end{tabular}

\begin{tabular}{|c|c|c|c|c|c|c|c|c|c|}
\hline \multirow{4}{*}{$\begin{array}{l}\text { No of cigarettes } \\
\text { smoked in home } \\
\text { per day in total } \\
\text { by parents }\end{array}$} & \multicolumn{8}{|c|}{$\%$ Children exposed } & \multirow{4}{*}{$\begin{array}{l}\text { Scotland } \\
1987 \text { and } \\
1988\end{array}$} \\
\hline & \multicolumn{8}{|l|}{ England } & \\
\hline & \multirow{2}{*}{$\begin{array}{l}\text { Representative } \\
\text { sample } 1988 \\
\text { (white) }\end{array}$} & \multicolumn{7}{|c|}{ Inner city areas 1987} & \\
\hline & & White & $\begin{array}{l}\text { Afro- } \\
\text { Caribbean }\end{array}$ & $U r d u$ & Gujarati & Punjabi & $\begin{array}{l}\text { Other } \\
\text { Asian }\end{array}$ & Other & \\
\hline $\begin{array}{c}0 \\
1-4 \\
5-14 \\
15-24 \\
25-34 \\
\geqslant 35\end{array}$ & $\begin{array}{r}70 \cdot 2 \\
3.8 \\
18.2 \\
6.6 \\
0.7 \\
0.6\end{array}$ & $\begin{array}{r}51 \cdot 1 \\
3.0 \\
24.3 \\
18 \cdot 0 \\
2.5 \\
1 \cdot 0\end{array}$ & $\begin{array}{r}69.0 \\
10.4 \\
16.9 \\
3.5 \\
0.2 \\
0.0\end{array}$ & $\begin{array}{r}67.9 \\
11.2 \\
16 \cdot 6 \\
3.2 \\
0.7 \\
0.4\end{array}$ & $\begin{array}{r}72.2 \\
11.9 \\
12.6 \\
2.5 \\
0.6 \\
0.2\end{array}$ & $\begin{array}{r}70 \cdot 6 \\
8 \cdot 1 \\
14 \cdot 6 \\
5 \cdot 9 \\
0 \cdot 4 \\
0.5\end{array}$ & $\begin{array}{r}46 \cdot 2 \\
6.3 \\
37.5 \\
9.5 \\
0 \cdot 0 \\
0.4\end{array}$ & $\begin{array}{r}53 \cdot 7 \\
9.4 \\
28.2 \\
6.3 \\
1.4 \\
1.0\end{array}$ & $\begin{array}{r}66.1 \\
2.8 \\
20.7 \\
8.3 \\
1.3 \\
0.9\end{array}$ \\
\hline $\begin{array}{l}\text { Total number } \\
\text { of children }\end{array}$ & 5633 & 1446 & 462 & 277 & 514 & 1333 & 253 & 490 & 3848 \\
\hline
\end{tabular}

DISTRIBUTION OF PARENTAL SMOKING

Data on parental smoking were available for 5116 English inner city children in $1987(74.7 \%$ of children of known ethnic origin), 2762 Scottish children in $1987(91.9 \%), 5868$ white English children in $1988(88.2 \%)$, and 1257 Scottish children in $1988(90.8)$. In total data for 135 children were omitted because either the number of parents in the home was unknown, or the child was in a single parent home with insufficient information. The distributions of number of cigarettes smoked per day by parents in the home are given in table II for each group and year. Parents of inner city white children smoked more than parents of the white 1988 representative sample. Smoking by Scottish parents was slightly heavier than that in the English 1988 representative sample.

Smoking was less prevalent in Asian parents, except for "Other Asian", and they were lighter smokers than parents of the 1988 white children. Afro-Caribbean parents were lighter smokers

Table IV Regression coefficient of child's height standard deviation score (SDS) on passive smoking by country, year of data collection, and by ethnic group in England 1987, adjusted for independent variables as shown in table $I$.

\begin{tabular}{|c|c|c|c|c|}
\hline & & $n$ & $\begin{array}{l}\text { Regression coefficient } \\
\text { of height SDS on total } \\
\text { cigarettes smoked at } \\
\text { home by parents }\end{array}$ & $\begin{array}{l}95 \% \text { Confidence } \\
\text { interval for } \\
\text { regression coefficient }\end{array}$ \\
\hline $\begin{array}{l}1987 \\
\text { England }\end{array}$ & $\begin{array}{l}\text { White } \\
\text { Afro-Caribbean } \\
\text { Urdu } \\
\text { Gujarati } \\
\text { Punjabi } \\
\text { Other Asian } \\
\text { Other }\end{array}$ & $\begin{array}{r}1236 \\
329 \\
110 \\
264 \\
600 \\
107 \\
257\end{array}$ & $\begin{array}{r}-0.0005 \\
-0.0057 \\
-0.0072 \\
0.0229 \\
0.0091 \\
-0.0126 \\
0.0022\end{array}$ & $\begin{array}{l}-0.0047 \text { to } 0.0036 \\
-0.0174 \text { to } 0.0060 \\
-0.0148 \text { to } 0.0274 \\
-0.0028 \text { to } 0.0485 \\
-0.0031 \text { to } 0.0212 \\
-0.0362 \text { to } 0.0110 \\
-0.0082 \text { to } 0.0127\end{array}$ \\
\hline \multicolumn{2}{|c|}{ Total inner city } & 2903 & 0.0012 & -0.0028 to 0.0052 \\
\hline \multicolumn{2}{|c|}{$\begin{array}{l}1988 \\
\text { England White }\end{array}$} & 5002 & -0.0010 & -0.0039 to 0.0020 \\
\hline \multicolumn{2}{|c|}{ Scotland $1987+1988$} & 3319 & 0.0008 & -0.0024 to 0.0040 \\
\hline \multicolumn{2}{|c|}{ Total $1987+1988$} & 11224 & 0.0003 & -0.0016 to 0.0022 \\
\hline
\end{tabular}

A regression coefficient of -0.01 would represent a decrease in height SDS -0.2 for a child whose parents smoke 20 cigarettes a day, ie, 1.0 to $1.4 \mathrm{~cm}$ depending on age. than the 1988 white parents, but heavier than Asian parents, except for "Other Asians".

Only 14 Asian mothers were reported to be smokers. The distribution of number of cigarettes smoked per day by the father in the home is shown in table III. The percentage of smokers in AfroCaribbean, Urdu, Gujarati, and Punjabi fathers was similar to that in the Caucasian representative sample, but the amount smoked was less. Other Asian and "Other" fathers were heavier smokers than representative sample fathers, but lighter smokers than white inner city fathers.

\section{RELATION OF HEIGHT TO PASSIVE SMOKING}

The regression coefficient of height standard deviation score on the number of cigarettes smoked in the home by parents per day, from the multiple regression analysis, including all the independent variables, is given in table IV for each ethnic group in 1987, the English 1988 white sample, and the Scottish sample. The 95\% confidence interval for the regression coefficient is also given, and the results for the total 1987 English sample, and overall total. The analyses of the 1987 English data and that of the total included the interactions of ethnic group with family size, birthweight, and parental heights. None of the regression coefficients of height standard deviation score on passive smoking was significantly different from zero.

PREVALENCE OF RESPIRATORY SYMPTOMS

The reported prevalence of each of the respiratory symptoms is given in table $\mathrm{V}$ for each sample by sex and by ethnic group for England 1987. The minimum sample size is given, which generally was for the bronchitis question, response to the other questions being slightly greater. Except for asthma attacks, the prevalence of each condition was greater for white inner city and AfroCaribbean boys than in the English 1988 white sample. Reported asthma attacks were particularly prevalent in Urdu boys. All ethnic 
minority and inner city boys had greater prevalence of cough than the 1988 white sample. Scottish boys had a similar prevalence of each condition to the 1988 English sample.

Prevalences were lower in the girls. Reported cough was very prevalent in Afro-Caribbean girls. Each condition except asthma was more prevalent in white inner city girls and Afro-Caribbean girls, and cough in all ethnic minority groups, than in the 1988 English sample. Scottish girls had the lowest reported prevalences, except for asthma attacks which were lowest in Gujarati girls.

\section{RELATION OF RESPIRATORY SYMPTOMS TO PASSIVE} SMOKING

Table VI shows the regression coefficient of each of the respiratory conditions on passive smoking from the multiple logistic regression, including independent variables as shown in table I. They are given, for boys and girls separately, for English white children in 1987 and 1988, and for the combined Scottish samples. A number of significant trends of increasing symptoms with greater passive smoking were found, most notably of the prevalence of "usually coughs", which showed a significant $(p<0.05)$ trend in English white inner city girls, and in English boys and girls $(p<0.01)$ in the 1988 representative sample. The prevalence of wheeze on most days or nights, ie, persistent wheeze, showed a significant $(p<0.05)$ positive relation for Scottish boys, and English white inner city girls, and prevalence of at least one condition had a significant positive relation in both samples of English girls.
Of the other regression coefficients of respiratory conditions on passive smoking in these groups, none was significantly different from zero $(p>0.05)$, but most were positive. The six regression coefficients for each condition were averaged, weighted by the inverse of their variances, and the results are given in the final column of table VI. All six trends were positive, and significantly different from zero for persistent wheeze and at least one condition $(p<0.01)$ and cough $(\mathrm{p}<0.001)$.

Data for Asian boys and Asian girls were analysed, but standard errors were too large to detect effects of the order of magnitude found in the larger samples. The smallest standard errors were for "at least one condition", for which the regression coefficient was -0.034 (SEM 0.022) $(\mathrm{p}<0.1)$ for boys and $0.023(0.021)$ for girls.

Standard errors have been given for reason of space, but $95 \%$ confidence intervals can be calculated as \pm 1.96 standard errors. For persistent wheeze, "usually coughs at other times", and "at least one condition" the average regression coefficients have been translated into relative risks estimated for parental smoking of 10 or 20 cigarettes a day at home, as shown in table VII. The baseline prevalence for no exposure was estimated from the multiple regression for the appropriate group. There was a greater estimated prevalence of symptoms for the baseline group in the inner city children than in either representative sample, so the differences in prevalence in table $\mathrm{V}$ are not entirely explained by the independent variables. These differences in
Table $V$ Prevalence $(\%)$ of respiratory conditions by sex, year, country and ethnic origin.

\begin{tabular}{|c|c|c|c|c|c|c|c|c|c|}
\hline \multirow[b]{3}{*}{$\begin{array}{l}\text { Respiratory } \\
\text { condition }\end{array}$} & \multicolumn{7}{|c|}{ England } & \multirow[b]{3}{*}{$\begin{array}{l}1988 \\
\text { White }\end{array}$} & \multirow{3}{*}{$\begin{array}{l}\text { Scotland } \\
1987 \text { and } \\
1988\end{array}$} \\
\hline & \multicolumn{7}{|c|}{1987 inner city areas } & & \\
\hline & White & $\begin{array}{l}\text { Afro- } \\
\text { Caribbean }\end{array}$ & $U r d u$ & Gujarati & Punjabi & $\begin{array}{l}\text { Other } \\
\text { Asian }\end{array}$ & Other & & \\
\hline $\begin{array}{l}\text { Chest EVER wheezy } \\
\text { or whistling }\end{array}$ & $19 \cdot 4$ & $19 \cdot 0$ & $15 \cdot 8$ & $11 \cdot 4$ & $\begin{array}{c}\text { ys (prevale } \\
11 \cdot 3\end{array}$ & $\begin{array}{l}\left.c e^{o} o\right) \\
17 \cdot 2\end{array}$ & $18 \cdot 4$ & $16 \cdot 3$ & $16 \cdot 1$ \\
\hline $\begin{array}{l}\text { Chest wheezy or } \\
\text { whistling on MOST } \\
\text { days or nights } \\
\text { In last } 12 \text { months: }\end{array}$ & $9 \cdot 4$ & 8.9 & $10 \cdot 9$ & $8 \cdot 6$ & $5 \cdot 5$ & $8 \cdot 6$ & $10 \cdot 4$ & $3 \cdot 8$ & $4 \cdot 2$ \\
\hline $\begin{array}{l}\text { Bronchitis attack(s) } \\
\text { Asthma attack(s) } \\
\text { Usually coughs }\end{array}$ & $\begin{array}{r}6 \cdot 3 \\
6 \cdot 8 \\
23 \cdot 4\end{array}$ & $\begin{array}{r}4 \cdot 4 \\
6 \cdot 5 \\
43 \cdot 4\end{array}$ & $\begin{array}{r}3 \cdot 9 \\
12 \cdot 3 \\
23 \cdot 5\end{array}$ & $\begin{array}{r}0 \cdot 7 \\
6 \cdot 8 \\
21 \cdot 7\end{array}$ & $\begin{array}{r}2 \cdot 8 \\
5 \cdot 3 \\
19 \cdot 2\end{array}$ & $\begin{array}{r}7 \cdot 9 \\
6 \cdot 3 \\
27 \cdot 5\end{array}$ & $\begin{array}{r}5 \cdot 2 \\
7 \cdot 6 \\
29 \cdot 0\end{array}$ & $\begin{array}{r}3 \cdot 4 \\
7 \cdot 6 \\
13 \cdot 6\end{array}$ & $\begin{array}{r}2 \cdot 8 \\
6 \cdot 9 \\
15 \cdot 2\end{array}$ \\
\hline Minimum sample size & 930 & 319 & 127 & 270 & 676 & 140 & 287 & 3137 & 2181 \\
\hline $\begin{array}{l}\text { Chest EVER wheezy } \\
\text { or whistling }\end{array}$ & $15 \cdot 5$ & $16 \cdot 0$ & $8 \cdot 3$ & $6 \cdot 6$ & $\begin{array}{l}\text { rls (prevale } \\
8.5\end{array}$ & $\begin{array}{c}\mathrm{ce}{ }_{0}^{o}, f_{1} \\
9 \cdot 6\end{array}$ & $12 \cdot 6$ & $11 \cdot 5$ & $9 \cdot 3$ \\
\hline $\begin{array}{l}\text { Chest wheezy or } \\
\text { whistling on MOST } \\
\text { days or nights } \\
\text { In last } 12 \text { months: }\end{array}$ & $7 \cdot 1$ & $9 \cdot 1$ & $3 \cdot 8$ & $3 \cdot 3$ & $5 \cdot 3$ & $5 \cdot 2$ & $6 \cdot 5$ & $2 \cdot 9$ & $2 \cdot 1$ \\
\hline $\begin{array}{l}\text { Bronchitis attack(s) } \\
\text { Asthma attack(s) } \\
\text { Usually coughs }\end{array}$ & $\begin{array}{r}4 \cdot 8 \\
3 \cdot 4 \\
20 \cdot 8\end{array}$ & $\begin{array}{r}4 \cdot 0 \\
3 \cdot 9 \\
39 \cdot 3\end{array}$ & $\begin{array}{r}1 \cdot 3 \\
3 \cdot 2 \\
21 \cdot 9\end{array}$ & $\begin{array}{r}1 \cdot 3 \\
2 \cdot 5 \\
23 \cdot 8\end{array}$ & $\begin{array}{r}2 \cdot 1 \\
3 \cdot 7 \\
15 \cdot 6\end{array}$ & $\begin{array}{r}3 \cdot 8 \\
3 \cdot 8 \\
19 \cdot 8\end{array}$ & $\begin{array}{r}3 \cdot 8 \\
5 \cdot 6 \\
29 \cdot 1\end{array}$ & $\begin{array}{r}2 \cdot 2 \\
4 \cdot 9 \\
12 \cdot 4\end{array}$ & $\begin{array}{r}1 \cdot 6 \\
3 \cdot 4 \\
11 \cdot 5\end{array}$ \\
\hline Minimum sample size & 865 & 326 & 152 & 236 & 663 & 131 & 260 & 2899 & 1969 \\
\hline
\end{tabular}

Table VI Regression coefficient from multiple logistic regression of respiratory conditions on passive smoking by sex, country, and sample, adjusted for independent variables as shown in table I

\begin{tabular}{|c|c|c|c|c|c|c|c|}
\hline \multirow{4}{*}{$\begin{array}{l}\text { Respiratory } \\
\text { condition }\end{array}$} & \multicolumn{7}{|c|}{ Regression coefficient (SE) (increase in logit [prevalence] per cigarette smoked in the home per day) } \\
\hline & \multicolumn{3}{|c|}{ Boys } & \multicolumn{3}{|l|}{ Girls } & \multirow{3}{*}{$\begin{array}{l}\text { Weighted } \\
\text { average }\end{array}$} \\
\hline & England & White & \multirow{2}{*}{$\begin{array}{l}\text { Scotland } \\
1987+1988\end{array}$} & England & White & \multirow{2}{*}{$\begin{array}{l}\text { Scotland } \\
1987+1988\end{array}$} & \\
\hline & 1987 & 1988 & & 1987 & 1988 & & \\
\hline $\begin{array}{l}\text { Chest EVER wheezy or whistling } \\
\text { Chest wheezy of whistling on MOST } \\
\text { days or nights } \\
\text { In last } 12 \text { months }\end{array}$ & $\begin{array}{l}-0.011(0.010) \\
-0.006(0.013)\end{array}$ & $\begin{array}{l}0.005(0.006) \\
0.012(0.011)\end{array}$ & $\begin{array}{l}0.010(0.007) \\
0.026(0.012)^{\star}\end{array}$ & $\begin{array}{l}0.019(0.010) \dagger \\
0.030(0.014) \star\end{array}$ & $\begin{array}{l}0.010(0.007) \\
0.016(0.013)\end{array}$ & $\begin{array}{r}-0.002(0.009) \\
0.025(0.017)\end{array}$ & $\begin{array}{l}0.006(0.003) \dagger \\
0.016(0.005) \ddagger\end{array}$ \\
\hline $\begin{array}{l}\text { Bronchitis } \\
\text { Asthma } \\
\text { Usually coughs } \\
\text { At least one condition }\end{array}$ & $\begin{array}{r}-0.034(0.019) \\
0.005(0.014) \\
0.002(0.010) \\
-0.005(0.009)\end{array}$ & $\begin{array}{c}0.008(0.013) \\
-0.001(0.009) \\
0.020(0.007) \ddagger \\
0.009(0.006)\end{array}$ & $\begin{array}{r}0.019(0.015) \\
-0.001(0.011) \\
0.006(0.008) \\
0.006(0.007)\end{array}$ & $\begin{array}{r}-0.029(0.022) \\
0.006(0.020) \\
0.021(0.009)^{\star} \\
0.017(0.009)^{\star}\end{array}$ & $\begin{array}{c}0.013(0.015) \\
-0.002(0.012) \\
0.019(0.007) \ddagger \\
0.013(0.006)^{\star}\end{array}$ & $\begin{array}{l}0.025(0.022) \\
0.001(0.015) \\
0.007(0.008) \\
0.002(0.007)\end{array}$ & $\begin{array}{l}0.004(0.007) \\
0.001(0.005) \\
0.013(0.003) \S \\
0.008(0.003) \ddagger\end{array}$ \\
\hline
\end{tabular}


prevalence were not sufficient to alter appreciably the relative risks from passive smoking, which were around 1.35 for persistent wheeze on exposure to 20 cigarettes smoked per day in the home and around 1.13 for the prevalence of at least one condition.

\section{Discussion}

The distribution of total parental smoking in the home in the English samples showed, as had been expected, heavier smoking by the inner city white parents than in the representative sample, and lighter smoking by Asian parents in most groups, mainly because few Asian mothers smoke. Parental smoking in Afro-Caribbean households was lower than in white inner city homes, due partly to the greater proportion of one parent families, and partly to a lesser proportion of smokers in Afro-Caribbean mothers $(31.4 \%)$ than in white inner city mothers $(56.4 \%)$. That was comparable to the proportion of white mothers in the representative sample $(28.5 \%)$ who smoked and of the Scottish mothers (35.9\%) who smoked. Afro-Caribbean fathers were reported to smoke less than white inner city fathers.

The 1987 and 1988 Scottish samples showed less heavy smoking than the 1982 sample. The difference between 1982 and 1988 was due to a heavy smoking area being replaced, by chance, by an area with a much lower smoking prevalence. As the 1987 and 1988 samples were comparable in the distribution of passive smoking it seems likely that the 1982 sample overestimated smoking by parents in Scotland. However the change may in part represent a real decline; the General Household Survey ${ }^{11}$ reported prevalence of smoking in Scotland in 1982 as $42 \%$ and in 1986 as $36 \%$ but a similar decline was seen in all areas of Great Britain, in contrast to the NSHG findings for England. The General Household Survey data are for all persons aged 16 or over, but parents in the NSHG are mainly young adults.

The results of the analysis of height standard deviation scores were consistent with there being no association between a child's height and parental smoking, in contrast to the previous conclusions drawn from the 1982 data analysis. ${ }^{1}$ Between 1982 and 1988 two English areas and one Scottish were replaced, and one English area and one Scottish had a change of school. The only substantive differences in confounding variables were that in 1982 the number of cigarettes smoked per day by the mother during her pregnancy with the child was asked, but in 1987 and 1988 only whether she smoked in that pregnancy was recorded; and in 1982 family size was included as a continuous variable, but in 1987 and 1988 as a categorical variable. The 1982 data were reanalysed using the same variables, exclusions and definitions as for the $1987 / 1988$ analyses, which gave an estimate of -0.0021 (SEM 0.0013, $0.05<\mathrm{p}<0.1)$ for the regression coefficient of height standard deviation score on number of cigarettes smoked in the home for 5380 English and Scottish children compared to -0.0034 for 5075 quoted by Rona, Chinn and Florey. ${ }^{1}$ Thus although larger, negatively, than the latest estimate, the 1982 regression coefficient would not have been regarded as statistically significant if estimated in the way now considered appropriate. Most of the difference is accounted for by the use of family size as a categorical variable rather than as a quantitative variable, as the relation between height standard deviation score and family size, whether measured by total siblings or number of older siblings, is not entirely linear.

Only about $5 \%$ of the 1988 sample were present in 1982, and so it is reasonable to combine the estimate of -0.0021 and that of 0.0003 from table IV, appropriately weighted, to give a final estimate of $-0.0006(95 \%$ CI -0.0021 to 0.0010).

Berkey et $a l^{7}$ reported a significant negative relation between the height of children aged 6 to 11 years with mother's smoking, and a negative but non-significant relation with father's smoking. They did not find a relation between rate of growth and parental smoking, and therefore concluded that the former association was due to smoke exposure during earlier childhood or in utero. As our estimates are with adjustment for birthweight and for whether the mother smoked in pregnancy with the child, our findings support the conclusion that there is no additional effect on height of passive smoking at ages 5-11 years, but do not exclude a long term effect of maternal smoking in pregnancy.

Our results confirmed the finding of Melia, Chinn and Rona $^{8}$ of greater prevalence of respiratory symptoms in inner city white children than in the representative sample, and also of greater prevalence of some symptoms in AfroCaribbeans.

The results for the individual samples in table

Table VII Estimates of prevalence (\%) of respiratory symptoms and relative risk for children of parents smoking no cigarettes, 10 cigarettes, and 20 cigarettes at home per day, using weighted average logistic regression coefficient, and individual group estimated baseline prevalence

\begin{tabular}{|c|c|c|c|c|c|c|c|}
\hline \multirow[b]{4}{*}{$\begin{array}{l}\text { Respiratory } \\
\text { condition }\end{array}$} & \multirow{4}{*}{$\begin{array}{l}\text { Cigarettes } \\
\text { smoked at } \\
\text { home by } \\
\text { parents }\end{array}$} & \multicolumn{6}{|c|}{ Prevalence $\%$ (relative risk compared to non-smoking parents) } \\
\hline & & \multicolumn{3}{|c|}{ Boys } & \multicolumn{3}{|l|}{ Girls } \\
\hline & & \multicolumn{2}{|c|}{ England (white) } & \multirow[b]{2}{*}{$\begin{array}{l}\text { Scotland } \\
1987+1988\end{array}$} & \multicolumn{2}{|c|}{ England (white) } & \multirow[b]{2}{*}{$\begin{array}{l}\text { Scotland } \\
1987+1988\end{array}$} \\
\hline & & $\begin{array}{l}987 \\
\text { (inner city) }\end{array}$ & 1988 & & $\begin{array}{l}1987 \\
\text { (inner city) }\end{array}$ & 1988 & \\
\hline $\begin{array}{l}\text { Chest wheezy or } \\
\text { whistling on MOST } \\
\text { days or nights } \\
\text { Usually coughs } \\
\text { At least one condition }\end{array}$ & $\begin{array}{r}0 \\
10 \\
20 \\
0 \\
10 \\
20 \\
0 \\
10 \\
20\end{array}$ & $\begin{array}{l}10 \cdot 6 \\
12.3(1 \cdot 16) \\
14 \cdot 1(1 \cdot 33) \\
22 \cdot 3 \\
24.8(1 \cdot 11) \\
27.3(1 \cdot 22) \\
26 \cdot 1 \\
27.6(1 \cdot 06) \\
29 \cdot 1(1 \cdot 12)\end{array}$ & $\begin{array}{l}3.0 \\
3.5(1 \cdot 17) \\
4.1(1.37) \\
13.4 \\
15 \cdot 1(1 \cdot 12) \\
16.9(1 \cdot 26) \\
19.0 \\
20.2(1.06) \\
21.5(1 \cdot 13)\end{array}$ & $\begin{array}{l}3.3 \\
3.9(1.17) \\
4.6(1.37) \\
15.9 \\
17.8(1.12) \\
19.8(1.25) \\
19.8 \\
21.1(1.06) \\
22.4(1.13)\end{array}$ & $\begin{array}{l}9.0 \\
10.4(1 \cdot 16) \\
12 \cdot 1(1 \cdot 34) \\
17.1 \\
19 \cdot 1(1 \cdot 12) \\
21.3(1 \cdot 24) \\
16.9 \\
18.0(1 \cdot 07) \\
19.1(1 \cdot 13)\end{array}$ & $\begin{array}{l}2.2 \\
2.6(1.17) \\
3.0(1.37) \\
8.5 \\
9.6(1.13) \\
10.8(1 \cdot 27) \\
15.1 \\
16.1(1.07) \\
17.2(1.14) \\
\end{array}$ & $\begin{array}{l}1.6 \\
1.8(1.17) \\
2.2(1.38) \\
9.6 \\
10.8(1.13) \\
12.2(1.27) \\
12.6 \\
13.5(1.07) \\
14.4(1.14)\end{array}$ \\
\hline
\end{tabular}

${ }^{2}$ Given for a child aged 8 years with no siblings, in a two parent family, father employed and social class IIIB, mother not smoking in pregnancy, home not overcrowded,

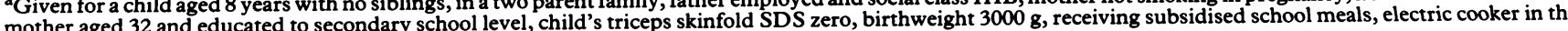
home. 
VI show several significant associations, but not consistently for one symptom or in one sample, and are therefore difficult to interpret. However there was no significant heterogeneity in the estimates, ${ }^{12}$ the largest $\chi^{2}$ value (5 degrees of freedom) being 9.63 for cough, and any real effect of passive smoking might be expected to be similar in these six samples, allowing for differences in overall prevalence and for differing effects of the confounding variables. In order to allow for the latter without encountering problems of fitting a large number of first order interactions in the multiple logistic regression, the weighted average $\mathrm{e}^{12}$ of the six estimates was used as the overall estimate. The limited sample size for Asian children, and smaller still for AfroCaribbean children, did not allow any possibility of detection of differences between groups. The results obtained for the Asian children were not included in the weighted average because respiratory symptoms may be variously perceived by different ethnic groups. ${ }^{8}$

The weighted average regression coefficients given in the final column of table VI are compatible with the fully adjusted coefficients given by Somerville, Rona and Chinn ${ }^{2}$ for the 1982 representative English sample. The current analysis confirms that the previous results were not due to confounding with effects of use of gas for cooking or of paraffin heaters, which could not be taken into account in the 1982 analysis. Although included as a potentially confounding variable we cannot entirely rule out a long term effect of maternal smoking in pregnancy producing an apparent relation between current symptoms and passive smoking, as this would require accurate data on the history of parental smoking throughout the pregnancy and the child's life and a sufficient proportion of parents who changed their habits. ${ }^{13}$

Data on active smoking by the children were again not collected in either 1987 or 1988 . In the previous paper ${ }^{2}$ it was considered that the prevalence of active smoking was too small to account for the findings. Goddard and Ikin ${ }^{14}$ found that smoking among first year secondary school children had declined from 1982 to 1986, so this explanation is now even less likely.

The combined results of the six samples are based on a total of nearly 10300 children, and is one of the largest studies, particularly of the 5-11 years age-group. Our previous finding was that if there is a real effect of passive smoking on respiratory symptoms in this age range then it is a small one, and requires a large study to show a statistically significant result, a conclusion borne out by the present analysis. The lower relative risk of 1.35 for persistent wheeze on exposure to 20 cigarettes a day smoked in the home, compared to 1.60 found previously, ${ }^{2}$ is close to 1.27 reported from the USA Six Cities Study, ${ }^{15}$ estimated from data for 6576 children aged 6-10 years.

However Ware et al gave relative risks only in relation to maternal smoking, because although significant relations were found with combined daily smoking of the father and mother, they found the strongest relation of symptoms to maternal smoking. This is not unexpected if, as in our data, maternal smoking at home formed a less variable proportion of total maternal smoking than did that of paternal smoking. As total maternal smoking is less than total home smoking by both parents, on average, we would have obtained a greater relative risk had we used total maternal smoking as the measure of exposure.

Newspiel et at gave an odds ratio of 1.49 for cumulative wheezy bronchitis to age 10 years in children of mothers who smoked 15-24 cigarettes a day compared to those who smoked none. The smoking estimate was an average of that smoked at the child's birth and that when the child was five. Wheezing in the first year was excluded but neither birthweight nor maternal smoking in pregnancy was allowed for. Much of the incidence may have occurred under age five, so their study does not provide an estimate of effects on children aged 5-10 years over and above any continuing effects of maternal smoking in pregnancy.

Inaccuracies in reported smoking will reduce the estimated relative risks, although a bias towards underreporting of smoking at home would increase the estimates. Repeatability data, not available to us at present, would help to address the first source of bias, but the second is unquantifiable. Hence calculation of confidence intervals for the relative risks from the data could be misleading. The estimates should be regarded as guidelines, from which, as relative risk varies very little with prevalence (table VII), we can obtain approximate figures for the risks of respiratory symptoms attributable to passive smoking. Using the passive smoking exposure frequencies in table II and the relative risks derived from the logistic regression coefficient of 0.008 for "at least one condition", we obtain the risk attributable ${ }^{16}$ to passive smoking in English white children in the representative sample as $4.2 \%$, in English white inner city children as $8.1 \%$, and in Scottish children as $5.2 \%$. If we apply the same relative risks to the other groups the estimates are $2.9 \%$ for Afro-Caribbean children, $1.7 \%$ for Urdu, $1.5 \%$ for Gujarati, $1.9 \%$ for Punjabi, $3.9 \%$ for Other Asians and $4.1 \%$ for Others. For persistent wheeze, in line with the greater relative risk, the attributable risks are higher, at $11.0 \%$ for English white children in the representative sample and $20.3 \%$ in the English white inner city children, although fewer absolute numbers are affected.

We cannot confirm an association between child's height and passive smoking for ages 5-11 years, but the relation of persistent wheeze to passive smoking constitutes a relative risk of around 1.35 on exposure to 20 cigarettes a day in the home, compared to no exposure, and the attributable risk of any respiratory symptom, particularly in inner city children, is not negligible.

We thank all the teachers, doctors, administrators, nurses, and clerks in the study areas for their generous assistance, and the fieldworkers and administrators of our Department. We thank Professor W W Holland for his continued encouragement and Mrs A Childs for producing the manuscript. The study is supported by the Department of Health and the Scottish Home and Health Department.

1 Rona RJ, Chinn S, Florey C du V. Exposure to cigarette smoking and children's growth. Int $\mathcal{F}$ Epidemiol 1985; 14: 
2 Somerville SM, Rona RJ, Chinn S. Passive smoking and respiratory conditions in primary school children. $\mathcal{f}$ Epidemiol Community Health 1988; 42: 105-10.

3 Surgeon General. The health consequences of involuntary smoking. Rockville, Maryland; USDHHS Office on smoking. Rockville, Marylan
Smoking and Health, 1986.

4 Fielding JE, Phenow KJ. Health effects of involuntary smoking. N Engl f Med 1988; 319: 1452-60.

5 Guyatt GH, Newhouse MT. Are active and passive smoking harmful? Determining causation. Chest 1985; 88: 445-51.

6 Newspiel DR, Rush D, Butler NR, Golding J, Bijur PE, Kurzon M. Parental smoking and post-infancy wheezing in children: a prospective cohort study. Am $\mathcal{F}$ Public Health 1989; 79: 168-71.

7 Berkey CS, Ware JM, Speizer FE, Ferris BG. Passive smoking and height growth of preadolescent children. Int $\mathcal{F}$ Epidemiol 1984; 13: 454-8.

8 Melia RJW, Chinn S, Rona RJ. Respiratory illness and home environment of ethnic groups. $B M \mathcal{F}$ 1988; 296: 1438-41.

9 Rona RJ, Chinn S. National Study of Health and Growth: social and biological factors associated with height of children from ethnic groups living in England. Ann Hum Biol 1986; 13: 453-71.

10 Tanner JM, Whitehouse RH, Takaishi M. Standards from birth to maturity for height, weight, height velocity and weight velocity. British children, 1965. Arch Dis Child 1966; 41: 454-71.

11 Office of Population Censuses and Surveys. General household survey 1986. Social Survey Division Series GHS No 16. London: HMSO, 1989.

12 Armitage P, Berry G. Statistical methods in medical research. Oxford; Blackwell Scientific Publications, 1987: 194.

13 Chinn S. Changing Exposure: passive smoking. Revue Chinn S. Changing Exposure: passive smoking. Rev
d'épidemiologie et de santé publique 1989; 37: 499-505.

14 Goddard E, Ikin C. Smoking among secondary school children in 1986. London: HMSO, 1987.

15 Ware JH, Dockery DW, Spiro A, Speizer FE, Ferris BG. Passive smoking, gas cooking and respiratory health of children living in six cities. Am Rev Respir Dis 1984; 129: 366-74.

16 Fleiss JL. Inference about population attributable risk from cross-sectional studies. Am $\mathcal{F}$ Epidemiol 1979; 110: 103-4. 